\title{
DETERMINAN PENGUNGKAPAN CSR DAN PENGARUHNYA TERHADAP NILAI PERUSAHAAN
}

\author{
Yulia Yunita Yusuf, Aulia Fuad Rahman, Endang Mardiati \\ Universitas Brawijaya Malang \\ Email: yuliayunitayusuf@yahoo.com
}

\begin{abstract}
The purpose of this study to test whether the slack resources, the company's financial leverage, firm size, and board size can be said as the determinant of the disclosure of Corporate Social Responsibility (CSR), and its influence on the value of the company. Results of a study of manufacturing companies indicates that slack resources, firm size, and board size affect the disclosure of CSR that are detrimental to the disclosure of CSR, and the company's financial leverage does not affect the disclosure of CSR. The test results also show that the direct effect of slack resources, the company's financial leverage, firm size, board size, and disclosure of CSR affect the value of the company. Results of testing analysis does not directly support the indirect effect of slack resources, company size, and the board size to corporate value through CSR, but the CSR was not able to mediate the effect of leverage on firm value. The results of this study support the stakeholder theory, slack resource theory, and good corporate governance theory.
\end{abstract}

Keywords: Slack resource, leverage, company size, board size, CSR disclosure, firm value.

\begin{abstract}
Abstrak: Tujuan penelitian ini untuk menguji apakah slack resource, leverage keuangan perusahaan, ukuran perusahaan, dan ukuran dewan komisaris dapat dikatakan merupakan determinan dari pengungkapan Corporate Social Responsibility (CSR), dan pengaruhnya terhadap nilai perusahaan. Hasil studi terhadap perusahaan manufaktur menunjukkan bahwa slack resource, ukuran perusahaan, dan ukuran dewan komisaris berpengaruh terhadap pengungkapan CSR sehingga merupakan determinan pengungkapan CSR, dan leverage keuangan perusahaan tidak berpengaruh terhadap pengungkapan CSR. Hasil uji pengaruh langsung juga menunjukkan bahwa slack resource, leverage keuangan perusahaan, ukuran perusahaan, ukuran dewan komisaris, dan pengungkapan CSR berpengaruh terhadap nilai perusahaan. Hasil analisis pengujian tidak langsung mendukung adanya pengaruh tidak langsung slack resource, ukuran perusahaan, dan ukuran dewan komisaris terhadap nilai perusahaan melalui pengungkapan CSR, namun pengungkapan CSR tidak mampu memediasi pengaruh leverage terhadap nilai perusahaan. Hasil studi ini mendukung stakeholder theory, slack resource theory, dan good corporate governance theory.
\end{abstract}

Kata Kunci: Slack resource, leverage, ukuran perusahaan, ukuran dewan komisaris, pengungkapan CSR, nilai perusahaan. 
Ketatnya persaingan dalam dunia bisnis menjadi pemicu yang kuat bagi manajemen perusahaan untuk menampilkan nilai terbaik dari perusahaan yang dipimpinnya. Salah satu sektor ekonomi yang mempunyai potensi untuk terus dikembangkan adalah industri manufaktur. Industri manufaktur merupakan industri yang mendominasi perusahaan-perusahaan yang terdaftar di Bursa Efek Indonesia (BEI). Banyaknya perusahaan dalam industri ini telah menciptakan suatu persaingan yang ketat sehingga membuat setiap perusahaan semakin meningkatkan kinerja agar tujuannya dapat tetap tercapai. Nilai perusahaan dapat dijadikan tolak ukur atas kinerja keuangan perusahaan. Indikator yang digunakan sebagai parameter untuk mengukur nilai perusahaan adalah Tobin's $q$. Tobin's $q$ adalah indikator untuk mengukur kinerja perusahaan, khususnya tentang nilai perusahaan, yang menunjukkan suatu performa manajemen dalam mengelola aktiva perusahaan. Nilai Tobin's $q$ menggambarkan suatu kondisi peluang investasi yang dimiliki perusahaan atau potensi pertumbuhan perusahaan (Lang et al. 1989). Nilai perusahaan yang terdaftar di BEI tiap tahunnya semakin berkurang. Berikut ini adalah data empiris mengenai nilai perusahaan pada perusahaan manufaktur sub sektor industri barang konsumsi yang terdaftar di Bursa Efek Indonesia tahun 2013 dan 2014:

Tabel 1. Tobin's $q$ Perusahaan Manufaktur Sub Sektor Industri Barang Konsumsi Tahun 2013 dan 2014

\begin{tabular}{ccccc}
\hline Tobin's q & Tahun 2013 & \multicolumn{3}{c}{ Tahun 2014 } \\
\hline & Jumlah Perusahaan & $\mathbf{\%}$ & Jumlah Perusahaan & $\%$ \\
$<1$ & 9 & 31 & 13 & 45 \\
$1,01-1,05$ & 11 & 38 & 9 & 31 \\
$1,51-2,00$ & 5 & 17 & 4 & 14 \\
$>2$ & 4 & 14 & 3 & 10 \\
\hline Total & $\mathbf{2 9}$ & $\mathbf{1 0 0 \%}$ & $\mathbf{2 9}$ & $\mathbf{1 0 0 \%}$ \\
\hline
\end{tabular}

Sumber: IDX, ICMD data diolah(2017)

Hasil pengolahan data dengan pengukuran Tobin's $q$ dapat dilihat pada tabel 1 yaitu jumlah perusahaan yang nilainya kurang dari 1 didapati meningkat dari $31 \%$ pada tahun 2013 menjadi $45 \%$ pada tahun 2014. Sementara itu rasio Tobin's q yang nilainya lebih dari 2 ditemukan berkurang dari $14 \%$ menjadi $10 \%$ pada tahun 2014. Berdasarkan data tersebut menunjukkan fenomena penurunan nilai perusahaan pada tahun 2014. Tentunya hal ini disebabkan oleh beberapa faktor, salah satunya adalah naik turunnya harga saham yang terjadi pada sub sektor ini. Fenomena ini terjadi diduga masih ada kaitannya dengan pergeseran paradigma single bottom line menjadi triple bottom line. "Satu-satunya tanggung jawab dalam perusahaan ialah meningkatkan keuntungannya" (Friedman, 1962). Itulah potongan pernyataan Milton Friedman, salah satu pemikir besar ilmu ekonomi yang kemudian banyak mendapat pertentangan karena mengasumsikan maksimisasi kekayaan pemegang saham melalui profit merupakan tujuan utama perusahaan. Pemikiran tersebut membuat perusahaan dituntut untuk mengejar laba sebesar-besarnya sehingga praktek bisnis pun mulai sedikit mengabaikan dampak negatif yang dirasakan oleh masyarakat dan lingkungan tempat perusahaan melakukan berbagai aktivitas produksi. Perusahaan lantas dianggap sebagai penyebab utama rusaknya lingkungan akibat eksploitasi sumber daya alam yang berlebihan (Capra, 1983).

Korporasi semestinya bertanggung jawab kepada pihak-pihak yang memiliki kepentingan, baik itu pihak internal maupun eksternal. Freeman (1984) berpendapat bahwa tanggung jawab perusahaanbukan hanya kepada pemegang saham, melainkan kelompok maupun individu yang dipengaruhi atau memengaruhi pencapaian tujuan perusahaan (stakeholders). Investor, sebagai salah satu stakeholders secara subyektif menyatakan ketertarikannya terhadap perusahaan yang mengungkapkan aktivitas sosial dalam laporan tahunan karena dipandang memiliki keunggulan tersendiri. CSR menjadi salah satu kewajiban yang juga harus dilaksanakan oleh perseroan terbatas sesuai dengan isi Bab V Pasal 74 Undang-undang No. 40 Tahun 2007 tentang Perseroan Terbatas (UUPT). UU 40/2007 pasal 74 ayat (1) menyatakan bahwa 
Perseroan yang menjalankan kegiatan usahanya di bidang dan/atau berkaitan dengan sumber daya alam wajib melaksanakan Tanggung Jawab Sosial dan Lingkungan.

Pada tahun 2012, implementasi program Corporate Social Responsibility (CSR) di Indonesia telah diperkuat dengan diterbitkannya Peraturan Pemerintah No.47/2012 tentang Tanggung Jawab Sosial dan Lingkungan (TJSL) Perseroan Terbatas, yang direalisasikan sejak awal April oleh pemerintah. Peraturan ini diharapkan dapat mengatur kewajiban tanggung jawab sosial perusahaan, dan dapat melengkapi UU No. 40 tahun 2007 tentang Perseroan Terbatas dan termuat dalam Pasal 74 yang mengatakan bahwa perseroan yang menjalankan kegiatan usahanya di bidang atau berkaitan dengan sumber daya alam wajib melaksanakan Tanggung Jawab Sosial dan Lingkungan. Peraturan Pemerintah No.47 Tahun 2012 yang menjadi landasan bahwa pengungkapan pertanggungjawaban sosial merupakan mandatory disclosure untuk setiap perusahaan di Indonesia, bukan lagi voluntary disclosure. Lebih khusus lagi Pernyataan Standar Akuntansi Keuangan (PSAK) No.1 (Revisi 2014) secara implisit menyarankan untuk mengungkapkan tanggung jawab akan masalah lingkungan dan sosial. Namun, berdasarkan hasil studi Perserikatan Bangsa-Bangsa (PBB) tentang Corporate Sustainability Report tahun 2013 membuktikan bahwa perusahaanperusahaan di Indonesia secara kolektif memiliki partisipasi yang rendah dalam hal melaporkan atau mengungkapkan aktivitas sosialnya. Hal ini mengindikasikan pengungkapan CSR (CSR disclosure) di Indonesia masih belum dipahami sebagai salah satu nilai tambah bagi perusahaan.

Sejalan dengan hasil studi PBB, National Center for Sustainability Reporting (NCSR), sebuah lembaga yang berfokus pada tujuan pembangunan berkelanjutan menyatakan bahwa perusahaan di Indonesia belum banyak yang menyediakan laporan CSR, yaitu 40 perseroan yang terdaftar di Bursa Efek Indonesia (BEI). Padahal, jika dilihat dari jumlah perseroan di Bursa Efek Indonesia yang berjumlah 519 emiten, seharusnya presentase perusahaan yang melaporkan laporan CSR-nya bisa lebih tinggi. NCSR memandang kesadaran perusahaan di Indonesia jauh lebih rendah dibandingkan dengan negara-negara maju seperti Jepang dan Prancis, yang diyakini telah memahami bahwa pengungkapan CSR menjadi salah satu alternatif strategi bisnis untuk membangun, dan melegitimasi posisi perusahaan di mata stakeholder-nya (Sayekti dan Ludovicus, 2007). Dalam akuntansi konvensional laporan keuangan perusahaan merupakan hasil transaksi perusahaan yang bisa jelas terlihat. Akan tetapi pertukaran perusahaan dengan lingkungannya bersifat non reciprocal yaitu transaksi antara keduanya tidak menimbulkan prestasi timbal balik. Hal inilah yang mengakibatkan informasi yang diterima oleh pihak pengguna informasi kurang lengkap terutama mengenai hal-hal yang berhubungan dengan tanggung jawab sosial perusahaan. Belum adanya standar baku dan berterima umum juga mengakibatkan informasi yang dituangkan beragam. Implikasinya, perusahaan akan mempertimbangkan biaya dan manfaat yang akan diperoleh ketika mereka memutuskan untuk mengungkapkan informasi sosial.

Adapun fokus peneltian ini adalah terletak pada faktor-faktor apa saja yang mempengaruhi keputusan perusahaan untuk melakukan pengungkapan CSR sebagai upaya untuk mencapai nilai perusahaan yang baik. Berdasarkan alur argumentasi di atas menggambarkan bahwa pemahaman perusahaan di Indonesia terhadap berbagai dampak positif dari pengungkapan CSR terhadap kinerja keuangan ternyata diidentifikasi masih sebatas voluntary atau dipandang hanya sebatas kegiatan formalitas yang bersifat temporary sehingga dibutuhkan studi lebih lanjut dan mendalam untuk mengetahui faktor-faktor yang menjadi penyebab kurangnya perhatian perusahaan dalam pengungkapan CSR.

\section{TINJAUAN PUSTAKA \\ Pengungkapan Corporate Social Respon- sibility}

Keputusan untuk memperlakukan CSR sebagai kebutuhan hakiki merupakan suatu keputusan investasi strategis yang akan membawa korporasi menikmati pertumbuhan laba dan kenaikan nilai pasar secara langgeng. Pendapat ini diperkuat oleh Lawrence dan Weber (2008) yang menyatakan jika suatu korporasi menjadikan CSR sebagai bagian dari visi dan strategi bisnisnya maka korporasi tersebut akan menikmati reputasi dan kenaikan nilai bisnis serta pertumbuhan laba dalam jangka panjang. Pengungkapan tanggung jawab 
sosial perusahaan akan dapat memberikan informasi kepada pihak-pihak yang terkait mengenai aktivitas sosial yang dilakukan oleh perusahaan. Menurut Hackston dan Milne (1996), pengungkapan tanggung jawab sosial perusahaan sering disebut sebagai corporate social responsibility atau social disclosure, corporate social reporting, social reporting merupakan proses pengomunikasian dampak sosial dan lingkungan dari kegiatan ekonomi organisasi terhadap kelompok khusus yang berkepentingan dan terhadap masyarakat secara keseluruhan.

\section{Teori Stakeholder}

Teori Stakeholder menyebutkan bahwa terdapat sekelompok orang atau individu yang diidentifikasi dapat memberikan pengaruh terhadap kegiatan perusahaan ataupun dapat dipengaruhi oleh kegiatan perusahaan (Freeman, 1983). Tujuan utama dari teori stakeholder adalah untuk membantu manajemen perusahaan dalam meningkatkan penciptaan nilai sebagai dampak dari aktivitasaktivitas yang mereka lakukan dan meminimalkan kerugian yang mungkin muncul bagi stakeholder mereka. Tujuan yang lebih luas dari teori stakeholder adalah untuk membantu manajer dalam meningkatkan nilai dampak kegiatan operasi perusahaan dan meminimalkan kerugian-kerugian bagi stakeholder.

\section{Teori Legitimasi}

Teori legitimasi mengandung pengertian bahwa aktivitas berupa tanggung jawab sosial perusahaan merupakan suatu usaha yang berkenaan dengan tekanan dari lingkungan sekitar, misalnya tekanan politis, sosial, ataupun ekonomi. Pihak manajemen berusaha untuk mencari kesepahaman di antara sudut pandang orang lain terhadap nilai sosial yang dimiliki serta apa yang dianggap oleh masyarakat sebagai dorongan sosial yang paling sesuai (Mathews, 1993). Teori legitimasi telah menjadi salah satu teori yang paling sering digunakan terutama ketika berkaitan dengan wilayah sosial dan akuntansi lingkungan.

\section{Slack Resource Theory}

Istilah kelonggaran (slack) pertama kali dicetuskan oleh March dan Simon dalam buku (seminal/pelopor) mereka di tahun 1958. Namun, Cyert dan March (1963) mendefinisikan kelonggaran sebagai selisih antara total sumber daya dengan total pembayaran yang harus dilakukan. Definisi ini digunakan oleh Bourgeois (1981) yang menambahkan bahwa kelonggaran adalah penahan (cushion) dalam bentuk sumber daya aktual maupun potensial yang memungkinkan sebuah organisasi beradaptasi secara sukses dari tekanan internal untuk melakukan penyesuaian atau dari tekanan eksternal untuk melakukan perubahan kebijakan, dan juga untuk menginisiasi perubahan strategi menghadapi lingkungan eksternal.

\section{Good Corporate Governance Theory}

Konsep corporate governance timbul karena adanya keterbatasan dari teori keagenan dalam mengatasi masalah keagenan dan dapat dipandang sebagai kelanjutan dari teori keagenan. Problem keagenan (agency problem) antara pemegang saham (pemilik perusahaan) dengan manager potensial terjadi bila manajemen tidak memiliki saham mayoritas perusahaan. Untuk menyakinkan bahwa manajer bekerja sungguh-sungguh untuk kepentingan pemegang saham, pemegang saham harus mengeluarkan biaya yang disebut agency cost meliputi pengeluaran untuk memonitor kegiatan manager, pengeluaran untuk membuat suatu struktur organisasi yang meminimalkan tindakan-tindakan manajer yang tidak diinginkan, serta opportunity cost yang timbul akibat kondisi manajer tidak dapat segera mengambil keputusan tanpa persetujuan pemegang saham (Atmadja, 2008: 13).

\section{Leverage}

Dasar pembentukan variabel ini adalah stakeholder theory. Stakeholder theory ini lahir akibat terjadinya pergeseran filosofis pengelolaan entitas bisnis. Awalnya pngelola (agen) mempunyai tanggung jawab perusahaan pada pemilik (principles). Namun perubahan tenologi dan komunikasi berubah ke manajemen moderen yang didasarkan pada teori stakeholder ini. Leverage menunjukkan proporsi atas penggunaan utang untuk membiayai investasi perusahaan. Kondisi perusahaan-perusahaan di Indonesia sangat bergantung pada utang bank untuk mendanai ekspansinya yang cepat karena pendanaan internal tidak memadai dan pasar modal belum berkembang dengan baik (Husnan, 2001). Dengan demikian, perusahaan publik di Indonesia sangat bergantung pada kreditur. Robert (1992) menyimpulkan bahwa keputusan struktur modal merupakan bagian 
dari strategi pemangku kepentingan perusahaan secara keseluruhan dan bahwa kreditur merupakan pemangku kepentingan penting yang mempengaruhi harus dikelola. Ini mengikuti bahwa semakin besar sejauh mana sebuah perusahaan bergantung pada pembiayaan utang untuk mendanai proyekproyek modal, semakin besar sejauh mana manajemen perusahaan akan diharapkan untuk menanggapi harapan kreditur mengenai peran korporasi dalam kegiatan tanggung jawab sosial.

\section{Slack Resource}

Slack resource theory dijadikan sebgai dasar dalam pembentukan variabel slack resource. Sumber daya diskresioner adalah kelonggaran organisasi (organizational slack). Organizational slack didefinisikan sebagai sumber daya yang tidak digunakan atau belum dikomitmenkan untuk tujuan apapun, atau sebagai ketersediaan sumber daya berlebih melampaui tingkat sumber daya minimal yang diperlukan untuk mempertahankan keutuhan dari organisasi (Cyert dan March, 1963) atau kelebihan sumber daya melampaui tingkat sumber daya yang diperlukan untuk menghasilkan tingkat output tertentu (Nohria dan Gulati, 1996). Para peneliti telah mengonseptualisasikan berbagai jenis kelonggaran sumber daya (seperti kelebihan bahan baku, tenaga kerja, kelebihan workinprocess, atau sisa kapasitas mesin), tetapi bentuk sumber daya yang paling diskresioner adalah kelebihan dana (Sharfman et al. 1988).

\section{Ukuran Dewan Komisaris}

Berdasarkan The National Committee on Corporate Governance (2000) dalam Okta (2010) menjelaskan beberapa hal yang berkaitan dengan dewan komisaris. Diantaranya adalah fungsi dewan komisaris untuk mengawasi direksi baik yang berhubungan dengan kebijakan dan pelaksanaan direksi. Kedua, dewan komisaris berfungsi untuk memberikan saran kepada direksi. Untuk menjalankan fungsi tersebut, maka anggota dewan komisaris merupakan seorang yang berkarakter baik dan memiliki pengalaman yang relevan. Ukuran dewan komisaris yang dimaksud adalah jumlah anggota dewan komisaris dalam perusahaan. Menurut Sembiring (2005) Berdasarkan teori agensi, dewan komisaris merupakan mekanisme pengendali intern tertinggi yang bertanggung jawab untuk memonitor tindakan manajemen puncak. Individu yang bekerja sebagai anggota dewan komisaris merupakan hal penting dalam memonitor aktivitas manajemen secara efektif.

\section{Ukuran Perusahaan}

Teori legitimasi memiliki alasan tentang hubungan ukuran dan pengungkapan tanggung jawab sosial (CSR). Perusahaan yang lebih besar melakukan aktivitas yang lebih banyak sehingga memiliki pengaruh yang lebih besar terhadap masyarakat, memilik lebih banyak pemegang saham yang punya perhatian terhadap program sosial yang dilakukan perusahaan dan laporan tahunan merupakan alat yang efisien untuk mengkomunikasikan informasi ini (Cowen et al., 1987). Semakin besar total aktiva, penjualan, dan kapitalisasi pasar, maka semakin besar pula ukuran perusahaan itu. Ketiga variabel tersebut dapat digunakan untuk menentukan ukuran perusahaan, karena dapat mewakili seberapa besar perusahaan tersebut.

\section{Nilai Perusahaan}

Tobin's $q$ adalah indikator untuk mengukur kinerja perusahaan, khususnya tentang nilai perusahaan, yang menunjukkan suatu proforma manajemen dalam mengelola aktiva perusahaan. Nilai Tobin's $q$ menggambarkan suatu kondisi peluang investasi yang dimiliki perusahaan (Lang et al., 1989) atau potensi pertumbuhan perusahaan (Tobin \& Brainard, 1968; Tobin, 1969). Nilai Tobin' $q$ dihasilkan dari penjumlahan nilai pasar saham (market value of all outstanding stock) dan nilai pasar hutang (market value of all debt) dibandingkan dengan nilai seluruh modal yang ditempatkan dalam aktiva produksi (replacement value of all production capacity), maka Tobin's $q$ dapat digunakan untuk mengukur kinerja perusahaan, yaitu dari sisi potensi nilai pasar suatu perusahaan. 


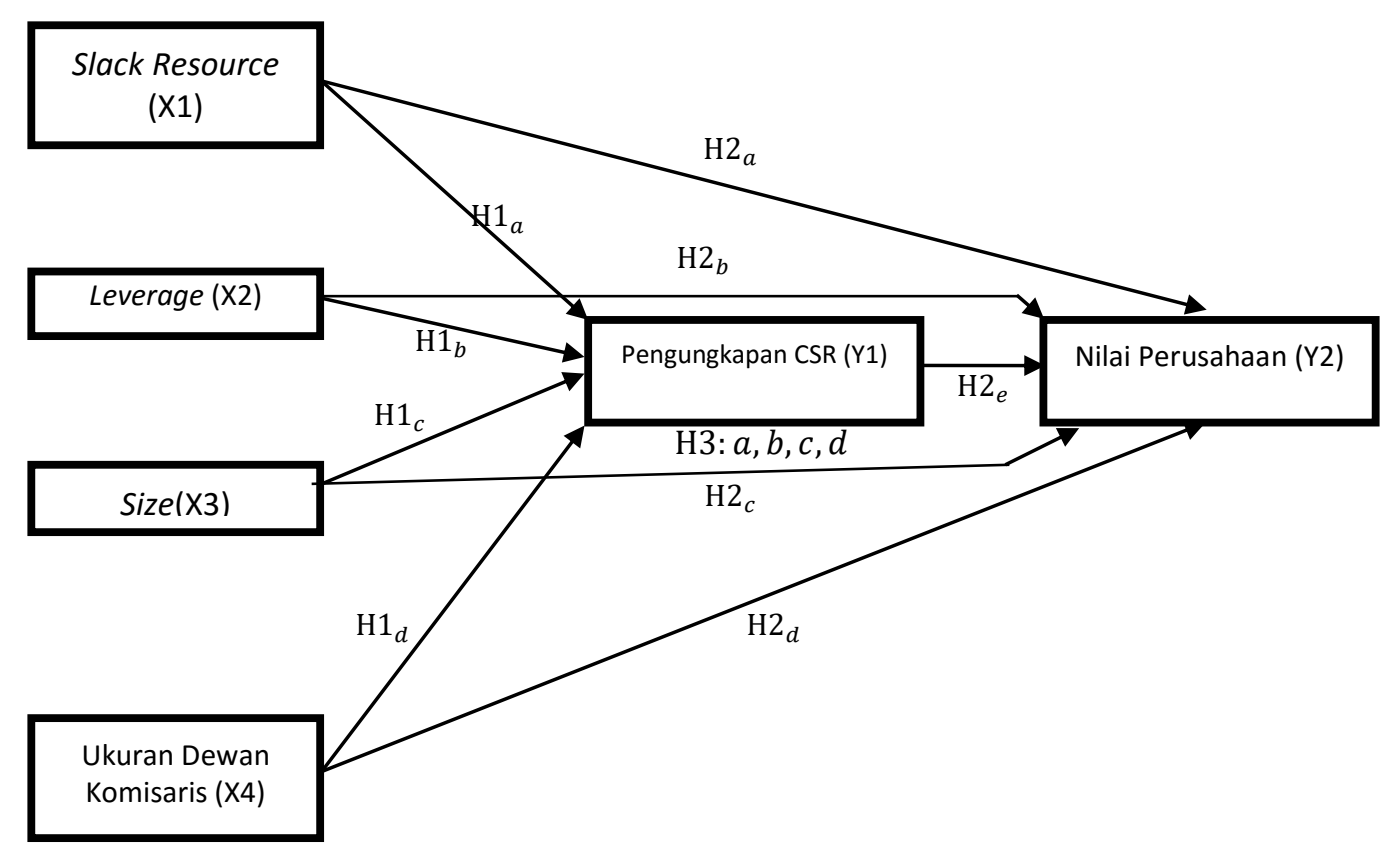

Gambar 1 Pengembangan Hipotesis

Pengaruh Slack Resource, Leverage, Ukuran Perusahaan, dan Ukuran Dewan Komisaris terhadap Pengungkapan CSR

Corporate Social Performance (CSP) merupakan kegiatan bersifat sukarela, sehingga pelaksanaan atau pembatalan kebijakan sosial dan lingkungan akan sangat bergantung pada ketersediaan dana lebih (McGuire, Sundgren, dan Schneeweis, 1988). Menurut teori kelonggaran sumber daya (Waddock dan Graves, 1997), kinerja ekonomi adalah prasyarat agar bisa mewujudkan kinerja sosial korporat yang baik, termasuk di dalamnya kinerja lingkungan. Implementasi dari dimensi CSP seperti pengembangan komunitas dan hubungan dengan pegawai, harus memiliki sumber daya finansial yang memadai. Dalam konteks pengungkapan lingkungan secara sukarela, slack resources dapat mendorong organisasi untuk melakukan lebih banyak pengungkapan karena tersedia sumber daya untuk memenuhi biaya administratif dalam melakukan pengungkapan itu.

\section{H1 ${ }_{a}$ : Slack resources berpengaruh positif terhadap pengungkapan CSR.}

Rasio leverage ini digunakan untuk memberikan gambaran mengenai struktur modal yang dimiliki perusahaan, sehingga dapat dilihat tingkat resiko tak tertagihnya suatu utang. Oleh karena itu perusahaan dengan rasio leverage yang tinggi memiliki kewajiban untuk melakukan pengungkapan yang lebih luas daripada perusahaan dengan rasio leverage yang rendah (Cho et al., 2012). Jika dikaitkan dengan teori legitimasi, perusahaan yang memiliki utang yang meningkat, perlu mengungkapkan Corporate Social Responsibility agar perusahaan tetap mendapatkan legitimasi, kepercayaan dan reaksi yang positif dari pihak lain.

\section{$H 1_{b}$ : Leverage keuangan perusahaan berpengaruh positif terhadap pengungkapan CSR perusahaan}

Secara teoritis perusahaan besar tidak akan lepas dari tekanan politis, yaitu tekanan untuk melakukan pertanggungjawaban sosial (Setiawati dan Artha, 2013). Teori legitimasi mengandung pengertian bahwa aktivitas berupa tanggung jawab sosial perusahaan merupakan suatu usaha yang berkenaan dengan tekanan dari lingkungan sekitar, misalnya tekanan politis, sosial, ataupun ekonomi.

\section{H1 $1_{c}$ : Ukuran perusahaan berpengaruh positif terhadap pengungkapan CSR perusahaan. \\ Keterbasan dari teori keagenan (agency} theory) dalam mengatasi masalah keagenan merupakan pemicu munculnya konsep corporate governance yang dapat dipandang sebagai kelanjutan teori keagenan. Dewan komisaris yang berasal dari luar perusahaan akan dipandang lebih baik karena pihak luar akan menetapkan kebijakan yang berkaitan 
dengan perusahaan secara lebih obyektif dibanding perusahaan yang memilki susunan dewan komisaris yang hanya berasal dari dalam perusahaan.

\section{H1 $1_{d}$ : Ukuran dewan komisaris perusahaan berpengaruh positif terhadap pengungkapan tanggung jawab sosial perusahaan.}

\section{Pengaruh Slack Resource, Leverage, Ukuran Perusahaan, Ukuran Dewan Komisaris, dan Pengungkapan CSR terhadap Nilai Perusahaan}

Menurut organizational theory, slack resources ditujukan untuk empat fungsi utama. Pertama, slack resources berfungsi sebagai ajakan, yang merepresentasikan 'besarnya pmbayaran kepada pemegang kepentingan melebihi apa yng diperlukan perusahaan untuk bertahan' (Tan dan Mike, 2003). Fungsi kedua yaitu slack resource dapat menjadi sumber daya untuk penyelesaian konflik. Ini berarti bahwa slack resource dapat menjadi salah satu solusi untuk setiap permasalahan. Fungsi ketiga dari slack resource yaitu berperan sebagai "penyangga" perusahaan dari kekacauan dan ketidakpastian lingkungan sekitar perusahaan. Fungsi terakhir yaitu, sebagai fasilitator perilaku strategis perusahaan, yang memungkinkan perusahaan untuk bereksperimen dengan strategi baru seperti memperkenalkan produk baru dan memasuki pasar yang baru (Thompson, 1967).

\section{H2 $a$ : Slack resource berpengaruh positif terhadap nilai perusahaan.}

Peningkatan leverage bisa memberikan dua macam signal, yaitu berita baik (good news) sekaligus berita buruk (bad news) (Novaes, 2002). Peningkatan leverage menunjukkan berita baik jika peningkatan tersebut merefleksikan kemampuan managemen untuk meningkatkan nilai. Sebaliknya, hal tersebut menunjukkan berita buruk jika manager melakukan peningkatan leverage karena terpaksa dan bukan karena alasan efisiensi. Leverage keuangan merupakan alternatif yang dapat digunakan untuk meningkatkan laba (Brigham dan Houston, 2001). Penggunaan hutang dalam investasi sebagai tambahan untuk mendanai aktiva perusahaan diharapkan dapat meningkatkan keuntungan yang akan diperoleh perusahaan, karena aktiva perusahaan digunakan untuk menghasilkan laba. Dengan demikian laba yang tersedia untuk pemegang ekuitas menjadi lebih besar (Brigham dan Houston 2001). Tetapi, penggunaan leverage yang semakin besar menyebabkan beban bunga semakin besar (Brigham dan Gapenski 1997). Jika beban bunga sangat besar sedangkan laba operasi tidak cukup besar, akan timbul masalah kesulitan keuangan yang menyebabkan kinerja menurun. Namun demikian beban bunga hutang juga merupakan pengurang pajak yang dapat meningkatkan nilai perusahaan (Brigham dan Gapenski 1997).

\section{$\mathrm{H} 2_{b}$ : Leverage keuanganperusahaan berpengaruh positif terhadap nilai perusahaan.}

Sehubungan dengan total akitva, apabila perusahaan memiliki total asset yang besar ini menunjukkan bahwa perusahaan telah mencapai tahap kedewasaan (maturity) atau well established. Secara umum perusahaan yang mempunyai total aktiva yang relatif besar dapat beroperasi dengan tingkat efisiensi yang lebih tinggi dibandingkan dengan perusahaan yang tingkat aktivanya rendah (Seniwati, 2008). Oleh karena itu perusahaan dengan total aktiva yang besar akan lebih mampu untuk menghasilkan tingkat keuntungan yang lebih tinggi. Ketika kinerja diukur dengan rasio tobin's q, peningkatan ukuran perusahaan yang ditandai dengan peningkatan aset secara signifikan berhubungan dengan kinerja yang lebih baik pada perusahaan sehingga peluang investasi menjadi lebih besar.

\section{H2 ${ }_{c}$ : Ukuran perusahaan berpengaruh positif terhadap nilai perusahaan.}

Dewan komisaris memegang peranan penting dalam mengarahkan strategi dan mengawasi jalannya perusahaan serta memastkan bahwa para manajer benar-benar meningkatkan kinerja perusahaan sebagai bagian dari tujuan perusahaan. Sari dan Putu (2014) menemukan bahwavariabel-variabel independen kepemilikan manajerial, salah satunya adalah ukuran dewan komisaris, berpengaruh positif terhadap nilai perusahaan yang diproksikan dengan price book value.Berdasarkan uraian tersebut, dapat dirumuskan hipotesis sebagai berikut:

\section{H2 ${ }_{d}$ : Ukuran dewan komisaris berpengaruh positif terhadap nilai perusahaan.}


Semakin besar kekuatan kelompokkelompok aktivis dan media dalam masyarakat yang plural, semakin perlu perusahaan membuat kegiatan strategis. Kegiatan CSR perusahaan merupakan kegiatan strategis yang dapat meningkatkan kinerja perusahaan. Hal ini sesuai pendapat Ullman (1985) bahwa kinerja sosial merupakan bentuk keberpihakan stakeholders yang mengandung konsekuensi ekonomi.

\section{H2 ${ }_{e}$ : Pengungkapan CSR berpengaruh positif terhadap nilai perusahaan.}

\section{Pengaruh Slack Resource, Leverage, Ukuran Perusahaan, dan Ukuran Dewan Komisaris terhadap Nilai Perusahaan Melalui Pengungkapan CSR Perusahaan}

Variabel pertama yang diduga menjadi determinan pengungkapan CSR adalah slack resources. Sejalan dengan fungsinya sebagai sebagai fasilitator perilaku strategis perusahaan, yang memungkinkan perusahaan untuk bereksperimen dengan strategi baru (Thompson, 1967), slack resource dapat mendukung salah satu strategi perusahaan yaitu tanggung jawab sosial. McGuire, Sundgren, dan Schneeweis (1988) menyatakan CSP merupakan kegiatan bersifat sukarela sehingga pelaksanaan atau pembatalan kebijakan sosial dan lingkungan akan sangat bergantung pada ketersediaan dana lebih. Hal ini didukung oleh Seifert et al. (2004); Fadliah (2014) yang menyatakan bahwa slack resource perpengaruh positif terhadap pengungkapan CSR. Saat perusahaan mengungkapkan tanggung jawab sosialnya setiap tahun, maka ini merupakan sinyal yang baik bagi pengguna laporan. Perusahaan berharap para pengguna laporan akan membaca "good news" kinerja perusahaan, misalnya dalam lingkup sosial, dan dengan demikian investor akan berinvestasi di perusahaan tersebut. Meningkatnya minat investor terhadap perusahaan, yang ditandai dengan semakin banyaknya saham yang beredar, tentu memberikan dampak positif terhadap harga saham.

\section{H3 ${ }_{a}$ : Terdapat pengaruh slack resource terhadap nilai perusahaan melalui pengungkapan CSR.}

Variabel kedua yang diangkat menjadi determinan pengungkapan CSR adalah leverage keuangan perusahaan. Perusahaan yang memiliki utang yang tinggi akan mempunyai risiko financial yang lebih besar sehingga akan menurunkan kepercayaan pihak lain atas kemampuan perusahaan dalam mengembalikan dana (Rofelawati, 2010). Jika dikaitkan dengan teori legitimasi, perusahaan yang memiliki utang yang meningkat, perlu mengungkapkan Corporate Social Responsibility agar perusahaan tetap mendapatkan legitimasi, kepercayaan dan reaksi yang positif dari pihak lain. Oleh karena itu perusahaan cenderung untuk mempersiapkan informasi secara terinci untuk meningkatkan kemungkinan bahwa mereka akan mendapatkan pendanaan dari institusiinstitusi finansial. Dengan mendapatkan legitimasi maka perusahaan tetap memegang kepercayaan pemilik dana untuk dipinjamkan ke perusahaan. Perolehan laba ini tentu akan menjadi pertimbangan para penanam modal untuk berinvestasi di perusahaan.

\section{H3 $3_{b}$ : Terdapat pengaruh antara leverage dengan nilai perusahaan melalui pengungkapan CSR.}

Selain slack resource dan leverage, size perusahaan merupakan variabel yang banyak digunakan untuk menjelaskan pengungkapan sosial yang dilakukan perusahaan dalam laporan tahunan yang dibuat (Belkaoui dan Karpik, 1989; Raffournier, 1995; Hackstone dan Milne, 1996, Cormier dan Magnan, 1999; Rofelawati, 2010; Sembiring, 2005; Setiawati dan Artha, 2013). Perusahaan yang berukuran lebih besar cenderung memiliki public demand akan informasi yang lebih tinggi dibanding perusahaan yang berkuran lebih kecil. Dengan pengungkapan tanggung jawab sosial dapat mengurangi biaya keagenan yang dikeluarkan sebab perusahaan yang berukuran lebih besar memiliki biaya keagenan yang lebih besar pula (Yulita, 2010). Perusahaan menggunakan kegiatan sosial untuk meningkatkan citra mereka di mata pemangku kepentingan. Belkaoui dan Karpik (1989) mengakui bahwa membangung citra dan adanya masalah kepentingan publik dapat memengaruhi keputusan untuk melakukan kegiatan tanggung jawab sosial tersebut.

\section{H3 $3_{c}$ : Terdapat pengaruh ukuran perusahaan terhadap nilai perusahaan melalui pengungkapan CSR.}

Selain beberapa determinan pengungkapan CSR yang telah disebutkan diatas, ukuran 
dewan komisaris juga memiliki andil yang besar dalam mendukung keberhasilan kinerja dari perusahaan. Dewan komisaris akan memberikan tekanan dalam bentuk pengawasan terhadap perusahaan dalam meningkatkan kinerja keuangan. Chtourou et al. (2001) dalam penelitiannya menyatakan bahwa dengan jumlah dewan komisaris yang semakin besar maka mekanisme monitoring manajemen perusahaan akan semakin baik. Hal tersebut didukung oleh hasil penelitian Rosenstein dan Wyatt (1990) yang menegaskan bahwa pasar modal bereaksi sangat baik terhadap pembentukan dewan komisaris dalam suatu perusahaan, yang ditandai dengan reaksi positif terhadap harga saham perusahaan. Ketika hubungan antara ukuran dewan komisaris dan pengungkapan CSR positif maka hal ini seharusnya dapat meningkatkan kinerja keuangan perusahaan.

\section{H3 ${ }_{d}$ : Terdapat pengaruh ukuran dewan komisaris terhadap nilai perusahaan melalui pengungkapan CSR.}

\section{METODE}

\section{Populasi, dan Sampel}

Populasi penelitian ini adalah kelompok industri sektor manufaktur yang terdaftar di Bursa Efek Indonesia (BEI) sejak tahun 2010 atau sebelumya sampai 2014. Penentuan sampel dalam penelitian ini dilakukan dengan menggunakan teknik purposive sampling, yaitu teknik judgement sampling (Hartono, 2010:79), kriteria yang digunakan untuk memilih sampel adalah: (1) Perusahaan manufaktur yang terdaftar di BEI sejak tahun 2010 atau sebelumnya, (2) Melakukan pengungkapan CSR selama tiga tahun berturut-turut mulai tahun 2011-2013, (3) Mempunyai laporan keuangan lengkap selama periode pengamatan berdasarkan data yang dibutuhkan.

\section{Variabel Penelitian dan Pengukuran Leverage}

Rasio pengukuran leverage perusahaan dalam penelitian ini diproksikan dengan Rasio Utang terhadap Ekuitas (Debt to Equity Ratio), yang diperoleh dengan cara total utang dibagi ekuitas. Rasio ini dipilih karena dianggap sebagai ukuran kekuasaan kreditur sebagai salah satu stakeholder karena rasio ini mewakili peran penting dari kreditur sebagai stakeholder dalam perbandingannya dengan para investor ekuitas (Belkaoui dan Karpik, 1989; Roberts, 1992; Purnomosidi, 2005).

\section{Slack Resources}

Penelitian ini mengukur slack resources mengadopsi pengukuran yang digunakan oleh Seifert et al. (2004) yaitu menggunakan relative cash flow. Relative cash flow diukur dengan cara:cash flow $\left(\mathrm{CF}_{\mathrm{t}-1}\right)$ dibagi dengan sales $\left(\mathrm{S}_{\mathrm{t}-1}\right)$.

\section{Ukuran Perusahaan}

Pada penelitian ini ukuran perusahaan diukur dengan menggunakan logaritma natural (Ln) dari total aktiva.

\section{Ukuran Dewan Komisaris}

Penelitian ini mengadopsi cara pengukuran Sembiring (2005) yaitu banyaknya jumlah anggota komisaris yang dimiliki.

\section{Pengungkapan Corporate Social Responsibility}

Pengungkapan CSR dalam penelitian ini diukur dengan menggunakan Global Reporting Initiatives (GRI) G4. GRIG4 menyediakan kerangka kerja yang relevan secara global untuk mendukung pendekatan yang terstandardisasi dalam pelaporan, yang mendorong tingkat transparansi dan konsistensi yangdiperlukan untuk membuat informasi yang disampaikan menjadi berguna dan dapat dipercaya oleh pasar dan masyarakat.

\section{Nilai Perusahaan}

Kinerja perusahaan berbasis pasar diproksikan dengan Tobin's $q$. Tobin's $q$ adalah gambaran statistik yang berfungsi sebagai proksi dari nilai perusahaan dari perspektif investor, seperti dalam defisisi yang telah dijelaskan di atas bahwa Tobin's $q$ merupakan nilai pasar dari firm's assets dan replacement value of those assets.

\section{Analisis Data \\ Analisis Jalur (Path Analysis)}

Analisis data yang digunakan dalam penelitian ini menggunakan Analisis Jalur (Path Analysis) dengan bantuan perhitungan melalui program Partial Least Square (PLS) menggunakan software Smart PLS. Untuk analisis jalur dengan variabel observed menggunakan PLS, tidak perlu melakukan pengukuran model untuk menguji validitas dan 
realibilitas sehingga langsung dilakukan estimasi model struktural.

\section{HASIL DAN PEMBAHASAN \\ Hasil Partial Least Square (PLS) \\ Pengujian Linieritas}

Pengujian linieritas dimaksudkan untuk mengetahui linier atau tidaknya hubungan antara variabel eksogen terhadap variabel endogen. Kriteria pengujian menyebutkan bahwa apabila nilai probabilitas <level of significance (alpha $(\alpha=5 \%)$ ) maka dinyatakan ada hubungan linier antara variabel eksogen terhadap variabel endogen. Hasil pengujian linieritas disajikan dalam tabel berikut :

Tabel 2. Hasil Pengujian Linearitas

\begin{tabular}{|c|c|c|c|}
\hline Eksogen & Endogen & $\mathbf{F}$ & Sig. \\
\hline Slack Resource & CSR & 431,204 & 0,000 \\
\hline Leverage & CSR & 301,321 & 0,000 \\
\hline Size & CSR & 69,339 & 0,000 \\
\hline $\begin{array}{l}\text { Ukuran Dewan } \\
\text { Komisaris }\end{array}$ & CSR & 349,673 & 0,000 \\
\hline Slack Resource & Nilai Perusahaan & 544,018 & 0,000 \\
\hline Leverage & Nilai Perusahaan & 410,127 & 0,000 \\
\hline Size & Nilai Perusahaan & 143,094 & 0,000 \\
\hline $\begin{array}{l}\text { Ukuran Dewan } \\
\text { Komisaris }\end{array}$ & Nilai Perusahaan & 311,300 & 0,000 \\
\hline CSR & Nilai Perusahaan & 666,138 & 0,000 \\
\hline
\end{tabular}

Berdasarkan tabel di atas diketahui bahwa semua hubungan antara variabel eksogen terhadap variabel endogen menghasilkan probabilitas sebesar 0,000. Hal ini berarti probabilitas <level of significance (alpha $(\alpha=5 \%))$. Dengan demikian dapat dinyatakan semua hubungan antara variabel eksogen terhadap variabel endogen adalah hubungan linier.

\section{Goodness of Fit Model}

Goodness of fit Model digunakan untuk mengetahui besarnya kemampuan variabel endogen untuk menjelaskan keragaman variabel eksogen, atau dengan kata lain untuk mengetahui besarnya kontribusi variabel eksogen terhadap variabel endogen. Goodness of fit Model dalam analisis PLS dilakukan dengan menggunakan $Q$-Square predictive relevance $\left(Q^{2}\right)$.

\begin{tabular}{lc}
\multicolumn{1}{c}{ Goodness of Fit Model } \\
\hline \multicolumn{1}{c}{ Variabel } & $\boldsymbol{R}^{2}$ \\
\hline Pengungkapan CSR & 0,879 \\
Nilai perusahaan & 0,859 \\
\hline $\mathrm{Q}^{2}=1-\left(1-\mathrm{R}_{1}{ }^{2}\right)\left(1-\mathrm{R}_{2}{ }^{2}\right) \rightarrow \mathrm{Q}^{2}$ & \\
$\quad=1-(1-0,879)(1-0,859)=0,982$ &
\end{tabular}

Kemudian $\quad R$-square variabel pengungkapan CSR bernilai 0,879 atau 87,9\%. Hal ini dapat menunjukkan bahwa keragaman variabel pengungkapan CSR mampu dijelaskan oleh variabel slack resource, leverage, ukuran perusahaan, dan ukuran dewan komisaris sebesar $87,9 \%$, atau dengan kata lain kontribusi variabel pengungkapan CSR mampu dijelaskan oleh variabel slack resource, leverage, ukuran perusahaan, dan ukuran dewan komisaris terhadap pengungkapan CSR sebesar 87,9\%, sedangkan sisanya sebesar $12,1 \%$ merupakan kontribusi variabel lain yang tidak dibahas dalam penelitian ini.

Selanjutnya $R$-square variabel nilai perusahaan bernilai 0,859 atau $85,9 \%$. Hal ini 
dapat menunjukkan bahwa keragaman variabel nilai perusahaan mampu dijelaskan oleh variabel slack resource, leverage, ukuran perusahaan, ukuran dewan komisaris dan pengungkapan CSR sebesar $85,9 \%$, atau dengan kata lain kontribusi variabel pengungkapan CSR mampu dijelaskan oleh variabel slack resource, leverage, ukuran perusahaan, ukuran dewan komisaris dan pengungkapan CSR terhadap nilai perusahaan sebesar $85,9 \%$, sedangkan sisanya sebesar $14,1 \%$ merupakan kontribusi variabel lain yang tidak dibahas dalam penelitian ini.

$Q$-Square predictive relevance $\left(Q^{2}\right)$ bernilai 0,982 atau $98,2 \%$. Hal ini dapat menunjukkan bahwa keragaman variabel nilai perusahaan mampu dijelaskan oleh model secara keseluruhan sebesar $98,2 \%$, atau dengan kata lain kontribusi variabel slack resource, leverage, ukuran perusahaan, ukuran dewan komisaris dan pengungkapan CSR terhadap nilai perusahaan secara keseluruhan sebesar $98,2 \%$, sedangkan sisanya sebesar $1,8 \%$ merupakan kontribusi variabel lain yang tidak dibahas dalam penelitian ini.

\section{Pengujian Pengaruh Langsung dan Tidak Langsung}

Penelitian ini melaukukan pengujian melalui dua tahap yaitu: Tahap pertama yaitu pengujian pengaruh langsung (direct effect) variabel independen $\mathrm{ke}$ variabel dependen.Tahap kedua adalah pengujian pengaruh tidak langsung (indirect effect) dilakukan dengan tujuan untuk menguji ada tidaknya pengaruh secara tidak langsung variabel independen terhadap variabel dependen melalui variabel interveningnya.

Tahap pertama dilakukan pengujian pengaruh langsung dengan kriteria pengujian menyatakan bahwa apabila nilai T-statistics $\geq$ T-tabel $(1,64)$ maka dinyatakan terdapat pengaruh signifikan variabel eksogen terhadap variabel endogen. Hasil pengujian direct effect dapat dilihat melalui ringkasan dalam tabel berikut ini:

Hasil Pengujian Direct Effect

\begin{tabular}{|c|c|c|c|c|c|}
\hline & Slack Resource & Leverage & $\begin{array}{c}\text { Ukuran } \\
\text { Perusahaan }\end{array}$ & $\begin{array}{c}\text { Ukuran } \\
\text { Dewan } \\
\text { Komisaris }\end{array}$ & $\begin{array}{c}\text { Pengungkapan } \\
\text { CSR }\end{array}$ \\
\hline $\begin{array}{c}\text { Pengungkapan } \\
\text { CSR }\end{array}$ & 5,914 & 0,814 & 2,237 & 8,828 & \\
\hline Nilai Perusahaan & 4,128 & 15,679 & 23,665 & 4,539 & 11,272 \\
\hline
\end{tabular}

Sumber : Data sekunder yang diolah (2017)

Diketahui terdapat tiga variabel yang secara langsung mempengaruhi pengungkapan CSR. Variabel slack resource, ukuran perusahaan dan ukuran dewan komisaris memiliki pengaruh langsung terhadap pengungkapan CSR dengan perolehan nilai Tstatistik $\geq 1,64$, namun variabel leverage tidak signifikan berpengaruh terhadap pengungkapan CSR dengan perolehan nilai T-statistik $\leq 1,64$. Terdapat lima variabel yang secara langsung mempengaruhi nilai perusahaan yaitu slack resource, leverage, ukuran perusahaan dan ukuran dewan komisaris.

Tahap kedua dilakukan pengujian pengaruh tidak langsung dengan kriteria pengujian menyatakan bahwa apabila nilai $\mathrm{T}$ statistics $\geq \mathrm{T}$-tabel $(1,64)$ maka dinyatakan terdapat pengaruh signifikan secara tidak langsung variabel eksogen terhadap variabel endogen melalui variabel interveningnya. Adapun hasil pengukuran pengaruh tidak lansung disajikan dalam tabel berikut ini:

Hasil Pengujian Indirect Effect

\begin{tabular}{|c|c|c|c|c|}
\hline & Slack Resource & Leverage & $\begin{array}{c}\text { Ukuran } \\
\text { Perusahaan }\end{array}$ & $\begin{array}{c}\text { Ukuran } \\
\text { Dewan } \\
\text { Komisaris }\end{array}$ \\
\hline $\begin{array}{c}\text { Pengungkapan } \\
\text { CSR }\end{array}$ & & & & \\
\hline Nilai Perusahaan & 5,237 & 0,812 & 2,194 & 6,950 \\
\hline
\end{tabular}

Sumber : Data sekunder yang diolah (2017) 
Diketahui bahwa terdapat pengaruh signifikan slack resource, ukuran perusahaan, dan ukuran dewan komisaris terhadap nilai perusaahaan melalui pengungkapan CSR dengan perolehan nilai Tstatistik $\geq 1,64$, namun tidak terdapat pengaruh signifikan leverage terhadap nilai perusahaan melalui pengungkapan CSR dengan perolehan nilai T-statistik lebih kecil dari 1,64.

\section{Konversi Diagram Jalur Ke Dalam Model Struktural}

Koefisien Direct dan Indirect Effect

\begin{tabular}{|l|l|l|l|l|l|}
\hline Eksogen & Endogen & Intervening & Direct & Indirect & Total \\
\hline Slack Resource & Pengungkapan CSR & & 0,434 & & 0,434 \\
\hline Leverage & Pengungkapan CSR & & 0,020 & & 0,020 \\
\hline Ukuran Perusahaan & Pengungkapan CSR & & 0,101 & & 0,101 \\
\hline $\begin{array}{l}\text { Ukuran Dewan } \\
\text { Komisaris }\end{array}$ & Pengungkapan CSR & & 0,454 & & 0,454 \\
\hline Slack Resource & Nilai Perusahaan & CSR & 0,082 & 0,148 & 0,230 \\
\hline Leverage & Nilai Perusahaan & CSR & 0,274 & 0,007 & 0,281 \\
\hline Ukuran Perusahaan & Nilai Perusahaan & CSR & 0,290 & 0,035 & 0,325 \\
\hline $\begin{array}{l}\text { Ukuran Dewan } \\
\text { Komisaris }\end{array}$ & Nilai Perusahaan & CSR & 0,103 & 0,155 & 0,259 \\
\hline Pengungkapan CSR & Nilai Perusahaan & & 0,342 & & 0,342 \\
\hline
\end{tabular}

Sumber : Data sekunder yang diolah (2017)

Berdasarkan tabel diatas dapat diketahui bahwa model pengukuran yang terbentuk adalah:

Persamaan 1

Pengungkapn CSR $=0,434$ slack resource $+0,020$ leverage $+0,101$ ukuran perusahaan $+0,454$ uk.dewan komisaris

Persamaan 2

Nilai Perusahaan $=0,082$ slack resource $+0,274$ leverage $+0,290$ ukuran perusahaan $+0,103$ uk.dewan komisaris $+0,342$ pengungkapan CSR

\section{Identidikasi Sifat Mediasi}

Pengaruh Slack Resource terhadap Nilai Perusahaan

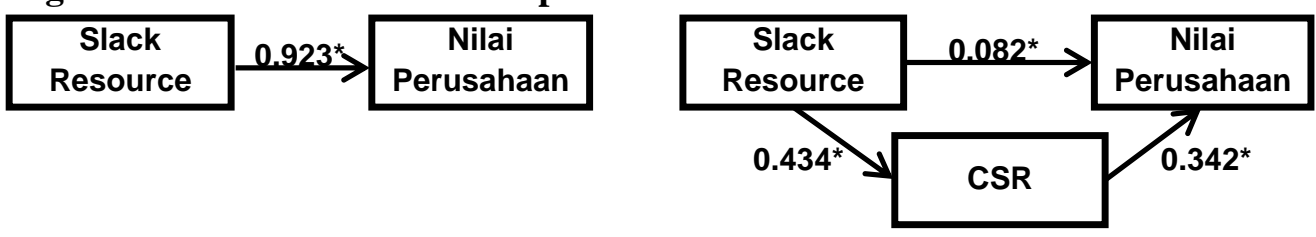

Berdasarkan ringkasan hasil yang ditunjukkan oleh diagram jalur di atas dapat diketahui bahwa pengaruh slack resource terhadap nilai perusahaan baik sebelum dan sesudah dimediasi dinyatakan signifikan dan koefisien jalur slack resource terhadap nilai

\section{Pengaruh Leverage terhadap Nilai Perusahaan}

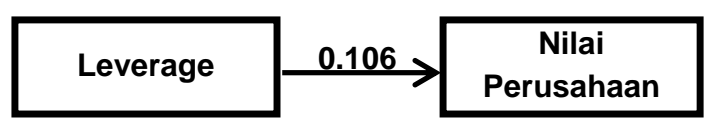

perusahaan sesudah dimediasi lebih kecil dari koefisien jalur slack resource terhadap nilai perusahaan sebelum dimediasi. Hal ini dapat dinyatakan variabel CSR mampu memediasi sebagian (partial mediation) slack resource terhadap nilai perusahaan.

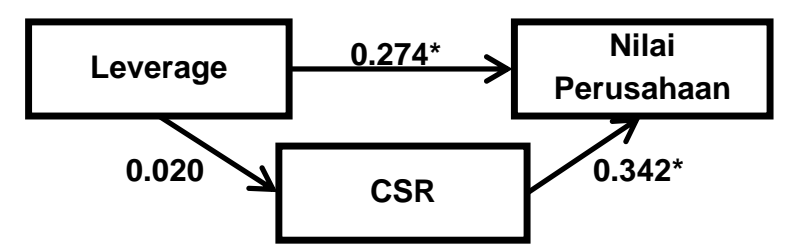


Berdasarkan ringkasan hasil yang ditunjukkan oleh diagram jalur di atas dapat diketahui bahwa pengaruh leverage terhadap CSR dinyatakan tidak signifikan dan pengaruh
CSR terhadap nilai perusahaan dinyatakan tidak signifikan. Hal ini dapat dinyatakan variabel CSR tidak mampu memediasi leverage terhadap nilai perusahaan.

\section{Pengaruh Ukuran Perusahaan terhadap Nilai Perusahaan}

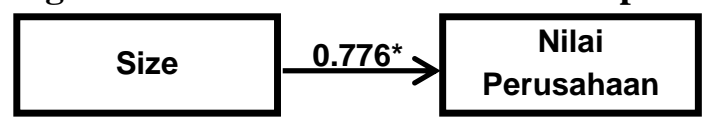

Berdasarkan ringkasan hasil yang ditunjukkan oleh diagram jalur di atas dapat diketahui bahwa pengaruh ukuran perusahaan terhadap nilai perusahaan baik sebelum dan sesudah dimediasi dinyatakan signifikan dan koefisien jalur ukuran perusahaan terhadap

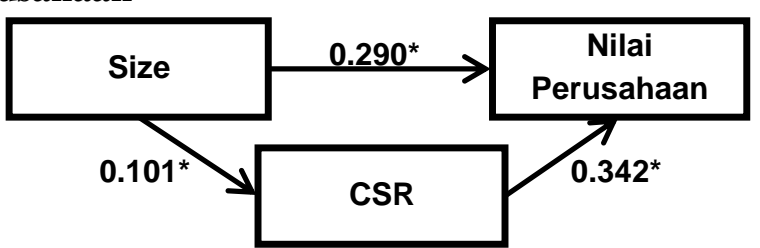

nilai perusahaan sesudah dimediasi lebih kecil dari koefisien jalur ukuran perusahaan terhadap nilai perusahaan sebelum dimediasi. Hal ini dapat dinyatakan variabel CSR mampu memediasi sebagian (partial mediation) ukuran perusahaan terhadap nilai perusahaan.

\section{Pengaruh Ukuran Dewan Komisaris terhadap Nilai Perusahaan}

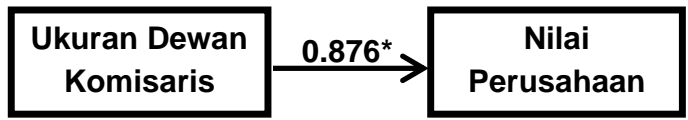

Berdasarkan ringkasan hasil yang ditunjukkan oleh diagram jalur di atas dapat diketahui bahwa pengaruh ukuran dewan komisaris terhadap nilai perusahaan baik sebelum dan sesudah dimediasi dinyatakan signifikan dan koefisien jalur ukuran dewan komisaris terhadap nilai perusahaan sesudah dimediasi lebih kecil dari koefisien jalur ukuran dewan komisaris terhadap nilai perusahaan sebelum dimediasi. Hal ini dapat dinyatakan variabel CSR mampu memediasi sebagian (partial mediation) ukuran dewan komisaris terhadap nilai perusahaan.

\section{Pengujian Hipotesis}

Hipotesis $1_{a}$ : Slack resource berpengaruh positif terhadap pengungkapan CSR

Hasil pengujian menunjukkan bahwa slack resource berpengaruh positif terhadap pengungkapan CSR dengan koefisien direct effect sebesar 0,434. Hasil ini signifikan yang ditunjukkan oleh nilai T-statistik $(5,914)$ lebih besar dari nilai T-tabel $(1,96)$. Hal ini berarti slack resource memiliki pengaruh positif signifikan terhadap pengungkapan CSR. Dengan demikian hipotesis $1_{a}$ diterima.

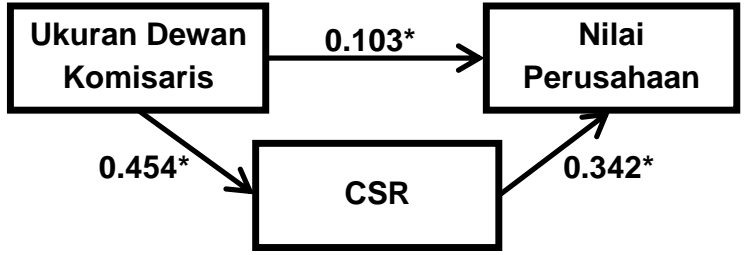

Berdasarkan hasil pengujian diperoleh bukti empiris bahwa $\mathrm{H} 1_{a}$ didukung dengan koefisien direct effect positif dan signifikan. Hal ini berarti semakin besar slack resource maka semakin banyak pengungkapan CSR yang dilakukan perusahaan. Temuan ini mendukung slack resource theory bahwa perusahaan dengan potensi sumber daya bebas yang tersedia akan memiliki kebebasan dalam memanfaatkan dananya untuk kepentingan sosial.

\section{Hipotesis $1_{b}$ : Leverage keuangan perusahaan berpengaruh positif terhadap pengungkapan CSR}

Hasil pengujian menunjukkan bahwa leverage berpengaruh positif terhadap pengungkapan CSR dengan koefisien direct effect sebesar 0,020. Hasil ini tidak signifikan yang ditunjukkan oleh nilai T-statistik $(0,814)$ lebih kecil dari nilai T-tabel $(1,96)$. Hal ini berarti leverage memiliki pengaruh positif tidak signifikan terhadap pengungkapan CSR. Dengan demikian hipotesis $1_{b}$ ditolak. Berdasarkan hasil pengujian diperoleh bukti empiris yang tidak mendukung $\mathrm{H} 1_{b}$ dengan 
koefisien direct effect positif namun tidak signifikan. Hal ini berarti semakin tinggi leverage maka cenderung dapat meningkatkan jumlah pengungkapan CSR yang dilakukan perusahaan. Meskipun leverage dapat meningkatkan pengungkapan CSR, namun peningkatan tersebut tidak signifikan. Hal ini berarti bahwa tinggi rendahnya tingkat leverage perusahaan cenderung tidak mempengaruhi luas pengungkapan tanggung jawab sosial perusahaan. Hasil ini menurut Chow dan Wong (1987) disebabkan antara lain, karena laporan tahunan yang di dalamnya terdapat pengungkapan CSR bukanlah satu-satunya sumber informasi untuk menyelesaikan masalah konflik kepentingan dari pemegang saham, kreditur, dan manajer perusahaan. Kreditur masih memiliki alternatif lain, misalnya debt covenant untuk mengamankan hutangnya dibandingkan dengan tingkat pengungkapan lebih. Kreditur juga dapat memperoleh informasi dan pengungkapan lainnya melalui tanya jawab langsung dengan manajemen, perjanjian hutang, laporan interim, ataupun dari laporan lainnya yang disediakan oleh perusahaan. Oleh karena kreditur masih memiliki berbagai alternatif informasi lain tersebutlah, maka kreditur tidak terlalu menuntut pengungkapan lebih pada laporan tahunan perusahaan.

\section{Hipotesis $1_{c}$ : Ukuran perusahaan berpengaruh positif terhadap pengungkapan CSR}

Hasil pengujian menunjukkan bahwa ukuran perusahaanberpengaruh positif terhadap pengungkapan CSR dengan koefisien direct effect sebesar 0,101. Hasil ini signifikan yang ditunjukkan oleh nilai T-statistik $(2,237)$ lebih besar dari nilai T-tabel $(1,96)$. Hal ini berarti semakin besar ukuran perusahaan maka semakin banyak pengungkapan CSR yang dilakukan perusahaan. Hasil penelitian menunjukkan bahwa ukuran perusahaan berpengaruh terhadap pengungkapan CSR. Hal ini menjelaskan bahwa pengungkapan CSR bergantung pada besar atau kecilnya suatu perusahaan. Penelitian ini berhasil mendukung teori legitimasi, yaitu perusahaan besar akan mengungkapkan tanggung jawab sosial lebih tinggi agar perusahaan tetap mendapatkan respon yang positif dari pihak lain (stakeholder), sehingga aktivitas usaha dapat berjalan dengan lancar. Untuk memenuhi kepentingan dari para stakeholder diperlukan pengungkapan informasi yang lebih banyak, termasuk pengungkapan CSR untuk menghindari tekanan dari pada stakeholder.

\section{Hipotesis $1_{d}$ : Ukuran dewan komisaris perusahaan berpengaruh positif terhadap pengungkapan CSR}

Hasil pengujian menunjukkan bahwa ukuran dewan komisarisberpengaruh positif terhadap pengungkapan CSR dengan koefisien direct effect sebesar 0,454. Hasil ini signifikan yang ditunjukkan oleh nilai T-statistik $(8,828)$ lebih besar dari nilai T-tabel $(1,96)$. Hal ini berarti ukuran dewan komisarismemiliki pengaruh positif signifikan terhadap pengungkapan CSR. Dengan demikian hipotesis $1_{d}$ diterima. Hal ini berarti semakin besar ukuran dewan komisaris maka semakin banyak pengungkapan CSR yang dilakukan perusahaan. Hasil penelitian ini menjadi bukti empiris bahwa adanya pengaruh ukuran dewan komisaris terhadap pengungkapan tanggung jawab sosial. Pengaruh ukuran dewan komisaris terhadap pengungkapan tanggung jawab sosial menunjukkan bahwa anggota dewan komisaris dapat berperan dan menjalankan fungsinya dalam memberikan kontrol dan monitoring bagi manajemen dalam menjalankan operasional perusahaan, termasuk dalam melaksanakan dan mengungkapkan aktivitas tanggung jawab sosial.

\section{Hipotesis $2_{a}$ : Slack resource berpengaruh positif terhadap nilai perusahaan}

Hasil pengujian menunjukkan bahwa slack resource berpengaruh positif terhadap nilai perusahaan dengan koefisien direct effect sebesar 0,082. Hasil ini signifikan yang ditunjukkan oleh nilai T-statistik $(4,128)$ lebih besar dari nilai T-tabel $(1,96)$. Hal ini berarti slack resource memiliki pengaruh positif signifikan terhadap nilai perusahaan. Dengan demikian hipotesis $2_{a}$ diterima. Hal ini berarti semakin besar slack resource maka dapat meningkatkan nilai perusahaan. Slack resource pada penelitian ini diproksikan dengan relative cash flow yang diperoleh dengan membandingkan total cash flow dengan sales.Cash flow merupakan sumber dana internal, yang dapat dijadikan modal untuk membiayai kegiatan perusahaan sehingga arus kas positif menjadi ukuran likuidita suatu perusahaan. Perusahaan dikatakan semakin likuid apabila arus kas positif yang yang 
dihasilkan semakin besar. Likuiditas perusahaan akan memberikan pengaruh terhadap penilaian atas kinerja perusahaan dan pada akhirnya akan meningkatkan nilai perusahaan di mata investor khususnya.

\section{Hipotesis $2_{b}$ : Leverage keuangan perusahaan berpengaruh positif terhadap nilai perusahaan}

Hasil pengujian menunjukkan bahwa leverage berpengaruh positif terhadap nilai perusahaan dengan koefisien direct effect sebesar 0,274. Hasil ini signifikan yang ditunjukkan oleh nilai T-statistik $(15,679)$ lebih besar dari nilai T-tabel $(1,96)$. Hal ini berarti leverage memiliki pengaruh positif signifikan terhadap nilai perusahaan. Dengan demikian hipotesis $2_{b}$ diterima. Hal ini berarti semakin tinggi leverage maka cenderung dapat meningkatkan nilai perusahaan. Hasil ini konsisten dengan hasil pendapat Modigliani dan Miller (1963) yang menyatakan bahwa jika terdapat pajak penghasilan perusahaan maka penggunaan hutang akan meningkatkan nilai perusahaan karena biaya bunga hutang adalah biaya yang mengurangi pembayaran pajak. Dengan adanya pengurangan pembayaran pajak maka earning after tax akan semakin meningkat dan dapat meningkatkan nilai perusahaan.

\section{Hipotesis $2{ }_{c}$ : Ukuran perusahaan berpengaruh positif terhadap nilai perusa- haan}

Hasil pengujian menunjukkan bahwa ukuran perusahaanberpengaruh positif terhadap nilai perusahaan dengan koefisien direct effect sebesar 0,290. Hasil ini signifikan yang ditunjukkan oleh nilai T-statistik $(23,665)$ lebih besar dari nilai T-tabel $(1,96)$. Hal ini berarti ukuran perusahaan memiliki pengaruh positif signifikan terhadap nilai perusahaan. Dengan demikian hipotesis $2_{c}$ diterima. Hal ini berarti semakin besar ukuran perusahaanmaka cenderung dapat meningkatkan nilai perusahaan. Hal ini dapat terjadi karena pasar menganggap makin besar ukuran perusahaan, maka kemampuan perusahaan makin tinggi dalam melakukan kegiatan atau kesempatan investasi yang lebih luas yang akhir-nya dapat meningkatkan nilai perusahaan.

\section{Hipotesis $2{ }_{d}$ : Ukuran dewan komisaris berpengaruh positif terhadap nilai perusahaan}

Hasil pengujian menunjukkan bahwa ukuran dewan komisarisberpengaruh positif terhadap nilai perusahaan dengan koefisien direct effect sebesar 0,103. Hasil ini signifikan yang ditunjukkan oleh nilai T-statistik $(4,539)$ lebih besar dari nilai T-tabel $(1,96)$. Hal ini berarti ukuran dewan komisarismemiliki pengaruh positif signifikan terhadap nilai perusahaan. Dengan demikian hipotesis $2_{d}$ diterima. Hal ini berarti semakin besar ukuran dewan komisaris maka semakin tinggi nilai perusahaan. Hal ini berarti bahwa pertambahan 1 orang anggota dewan komisaris dapat meningkatkan efektivitas pengambilan keputusan, waktu yang digunakan dalam pengambilan keputusan dapat lebih efisien dan keputusan yang diambil memiliki kualitas yang lebih baik.

\section{Hipotesis $2 e_{e}: \quad$ Pengungkapan CSR berpengaruh positif terhadap nilai peru- sahaan}

Hasil pengujian menunjukkan bahwa pengungkapan CSR berpengaruh positif terhadap nilai perusahaan dengan koefisien direct effect sebesar 0,342. Hasil ini signifikan yang ditunjukkan oleh nilai T-statistik $(11,272)$ lebih besar dari nilai T-tabel $(1,96)$. Hal ini berarti pengungkapan CSRmemiliki pengaruh positif signifikan terhadap nilai perusahaan. Dengan demikian hipotesis $2_{e}$ diterima. Hal ini berarti semakin banyak pengungkapan CSR yang dilakukan perusahaanmaka cenderung dapat meningkatkan nilai perusahaan. Hasil ini menunjukkan bahwa keberpihakan perusahaan kepada kepentingan sosial dapat meningkatkan nilai perusahaan. Temuan ini mendukung pendapat Ullman (1985) bahwa kinerja sosial merupakan bentuk keberpihakan kepada stakeholder yang mengandung konsekuensi ekonomi.

Hipotesis $3_{a}$ : Terdapat pengaruh slack resource terhadap nilai perusahaan melalui pengungkapan CSR

Hasil pengujian menunjukkan bahwa slack resource berpengaruh positif terhadap nilai perusahaan melalui pengungkapan CSR dengan koefisien indirect effect sebesar 0,148. Hasil ini signifikan yang ditunjukkan oleh nilai $\mathrm{T}$ statistik $(5,237)$ lebih besar dari nilai T-tabel $(1,96)$. Hal ini berarti pengungkapan CSR memiliki peran mediasi terhadap hubungan antara slack resource dengan nilai perusahaan. Dengan demikian hipotesis $3_{a}$ diterima. 


\section{Hipotesis $3_{b}$ : Terdapat pengaruh leverage keuangan perusahaan terhadap nilai perusahaan melalui pengungkapan CSR}

Hasil pengujian menunjukkan bahwa leverage berpengaruh positif terhadap nilai perusahaan melalui pengungkapan CSR dengan koefisien indirect effect sebesar 0,007. Hasil ini tidak signifikan yang ditunjukkan oleh nilai $\mathrm{T}$ statistik $(0,812)$ lebih kecil dari nilai T-tabel $(1,96)$. Hal ini berarti pengungkapan CSRtidak memiliki peran mediasi terhadap hubungan antara leverage dengan nilai perusahaan. Dengan demikian hipotesis $3_{b}$ ditolak.

\section{Hipotesis $3_{c}$ : Terdapat pengaruh ukuran perusahaan terhadap nilai perusahaan melalui pengungkapan CSR}

Hasil pengujian menunjukkan bahwa ukuran perusahaanberpengaruh positif terhadap nilai perusahaan melalui pengungkapan CSR dengan koefisien indirect effect sebesar 0,035. Hasil ini signifikan yang ditunjukkan oleh nilai T-statistik $(2,194)$ lebih besar dari nilai T-tabel $(1,96)$. Hal ini berarti pengungkapan CSR memiliki peran mediasi terhadap hubungan antara ukuran perusahaandengan nilai perusahaan. Dengan demikian hipotesis $3_{c}$ diterima.

\section{Hipotesis $3_{d}$ : Terdapat pengaruh ukuran dewan komisaris terhadap nilai perusahaan melalui pengungkapan CSR}

Hasil pengujian menunjukkan bahwa ukuran dewan komisarisberpengaruh positif terhadap nilai perusahaan melalui pengungkapan CSR dengan koefisien indirect effect sebesar 0,155. Hasil ini signifikan yang ditunjukkan oleh nilai T-statistik $(6,950)$ lebih besar dari nilai T-tabel $(1,96)$. Hal ini berarti pengungkapan CSRmemiliki peran mediasi terhadap hubungan antara slack resource dengan nilai perusahaan. Dengan demikian hipotesis $3_{d}$ diterima.

\section{Hipotesis $\mathrm{H3}_{a, b, c, d}$}

Berdasarkan hasil pengujian diperoleh bukti empiris bahwa slack resource, ukuran perusahaan dan ukuran dewan komisaris berpengaruh terhadap nilai perusahaan melalui pengungkapan CSR, didukung dengan koefisien indirect effect positif dan signifikan. Hal ini berarti meningkatnya pengungkapan CSR yang disebabkan oleh semakin besarnya slack resource,ukuran perusahaan, dan ukuran dewan komisaris dapat meningkatkan nilai perusahaan. Namun berbeda dengan leverage dengan koefisien indirect effect positif namun tidak signifikan, yang berarti semakin tinggipengungkapan CSR yang disebabkan oleh semakin tingginya leverage, cenderung dapat meningkatkan nilai perusahaan.Meskipun leverage mampu meningkatkan nilai perusahaan melalui pengungkapan CSR, namun peningkatan tersebut tidak signifikan.

Pengungkapan CSR dapat memediasi hubungan antara slack resource dengan nilai perusahaan karena pengungkapan CSR menjadi salah satu strategi bisnis untuk menunjang keberlangsungan perusahaan di masa mendatang. CSR merupakan gagasan yang berpijak dalam lingkungan, ekonomi dan sosial. Dari perspektif ekonomi, perusahaan yang mengungkapkan informasi yang lebih akan memberikan nilai labih bagi perusahaannya. Perusahaan akan mendapatkan nilai lebih di mata masyarakat dan dapat memaksimalkan keuangan perusahaan dalam jangka panjang. Slack resource theory menyatakan bahwa perusahaan yang memiliki potensi ketersediaan sumber daya bebas dari kinerja keuangan yang bagus akan memiliki kebebasan membelanjakan dananya untuk kepentingan sosial.

Temuan dari penelitian ini didukung oleh pendapat dari Waddock dan Graves (1997) bahwa suatu perusahaan terlebih dahulu harus fokus pada kinerja keuangan agar dapat memiliki sumber dana lebih untuk merealisasikan kebijakan sosial perusahaan. Perusahaan yang sehat secara keuangan akan lebih mudah melakukan pemenuhan kewajiban kepada pemegang saham dan tekanan dari stakeholder keuangan lain juga menjadi lebih kecil. Sehingga apabila perusahaan memiliki slack pada sumber dayanya, perusahaan akan lebih leluasa dalam membelanjakan dananya untuk aktivitas sosial dan pengungkapannya, sehingga mampu memenuhi kewajibannya kepada seluruh stakeholder.

Selain hubungan antara slack resource dengan nilai perusahaan mampu dimediasi oleh pengungkapan CSR, ukuran perusahaan berpengaruh terhadap nilai perusahaan juga dapat dimediasi oleh pengungkapan CSR. Peningkatan pengungkapan CSR perusahaan yang didorong oleh semakin besarnya ukuran peruahaan akan meningkatkan nilai perusahaan. Perusahaan besar, yang memiliki aset yang 
besar, akan mendapatkan perhatian yang lebih dari masyarakat. Public demand akan informasi menjadi tuntutan bagi perusahaan yang lebih besar. Oleh sebab itu, untuk memenuhi kepentingan dari para stakeholder diperlukan pengungkapan informasi yang lebih banyak, termasuk pengungkapan sukarela CSR untuk menghindari tekanan dari para stakeholder.

Perusahaan besar, yang mendapatkan perhatian lebih dari masyarakat, manggunakan kegiatan sosial sebagai sarana menekan tuntutan dari stakeholder. Sejalan dengan the political cost hypotesis yang menyatakan bahwa semakin besar perusahaan semakin banyak stakeholder yang terlibat dengan beraneka macam kepentingan masing-masing. Oleh karena itu, diperlukan pengungkapan informasi yang lebih banyak untuk memenuhi kepentingan dari para stakeholder, termasuk pengungkapan sukarela CSR untuk menghindari tekanan sehingga mampu menciptakan kondisi stabil perusahaan. Weston dan Copeland (1999) berpendapat bahwa keputusan yang menyangkut besarnya perusahaan merupakan salah satu keputusan di bidang keuangan yang berpengaruh pada besaran arus kas dan tingkat resiko yang dihadapi perusahaan sehingga akan berakibt pada tingkat harga saham perusahaan.

Pengungkapan CSR juga dapat memediasi hubungan antara ukuran dewan komisaris dengan nilai perusahaan. Dewan komisaris sebagai pemegang kendali yang bertanggungjawab untuk memonitor tindakan manajemen puncak dan memiliki andil dalam mendukung keberhasilan kinerja perusahaan. Dewan komisaris akan memberikan tekanan kepada manajemen dalam bentuk pengawasan terhadap perusahaan dalam meningkatkan kinerja keuangan. Dengan jumlah dewan komisaris yang semakin besar maka mekanisme monitoring perusahaan semakin baik dan pasar modal bereaksi sangat baik terhadap pembentukan dewan komisaris dalam suatu perusahaan (Rosenstein dan Wyatt, 1990).

Sejalan dengan konsep corporate governance yang didasarkan pada teori keagenan, bahwa dewan komisaris berfungsi sebagai salah satu indikator yang dapat menjamin efektif dan efisien jalannya perusahaan agar memberikan keyakinan kepada investor bahwa mereka akan menerima return atas dana yang telah mereka investasikan. Dengan adanya dewan komisaris yang dapat memonitor penerapan corporate governance ini maka perusahaan dapat memaksimalkan nilai perusahaan agar memiliki daya saing yang kuat untuk mendukung iklim investasi.

Dewan komisaris sebagai pihak yang mampu mendorong pengelolaan perusahaan secara profesional, transparan, dan efisien. Salah satu upaya pencapaian nilai perusahaan yang baik yaitu dengan mendorong manajer untuk melakukan pengungkapan CSR sebagai upaya akuntabilitas dan transparansi berdasarkan prinsip good corporate governance. Menjalankan perusahaan dengan dilandasi nilai moral yang tinggi dan kepatuhan terhadap UU dan ketentuan yang berlaku serta kesadaran perusahaan tentang adanya tanggung jawab sosial kepada pihak-pihak yang berkepentingan merupakan tujuan yang ingin dicapai dalam upaya melaksanakan tata kelola perusahaan yang baik.

Selain slack resource, ukuran perusahaan, dan ukuran dewan komisaris, hasil penelitian ini tidak dapat membuktikan bahwa leverage merupakan determinan atas pengungkapan CSR. Hal ini mengindikasikan bahwa meskipun leverage dapat meningkatkan pengungkapan CSR, namun peningkatan tersebut tidak signifikan. Hal ini disebabkan karena kreditur masih memiliki berbagai alternatif informasi lain selain pengungkapan tanggung jawab sosial, maka kreditur tidak terlalu menuntut pengungkapan lebih pada laporan tahunan perusahaan. Kendali kreditur yang terbatas hanya pada return dan pengembalian hutang berjangka waktu tertentu dan tidak memiliki hak suara sehingga tuntutan kepada perusahaan untuk memenuhi tanggung jawab sosial rendah. Oleh karena itu pengungkapan CSR tidak memliki peran mediasi terhadap hubungan antara leverage dengan nilai perusahaan.

Ringkasan Hasil Pengujian Hipotesis

\begin{tabular}{|c|c|c|c|c|c|}
\hline $\begin{array}{c}\text { Hipot } \\
\text { esis }\end{array}$ & Eksogen & Endogen & Intervening & $\begin{array}{c}\text { Koefisien Jalur } \\
\text { (T-Statistik) }\end{array}$ & Keterangan* \\
\hline $\mathrm{H} 1_{a}$ & Slack resource & $\begin{array}{c}\text { Pengungkapan } \\
\text { CSR }\end{array}$ & & D $0,434(5,914)$ & Terima \\
\hline
\end{tabular}




\begin{tabular}{|c|c|c|c|c|c|}
\hline $\begin{array}{l}\text { Hipot } \\
\text { esis }\end{array}$ & Eksogen & Endogen & Intervening & $\begin{array}{c}\text { Koefisien Jalur } \\
\text { (T-Statistik) }\end{array}$ & Keterangan* \\
\hline $\mathrm{H} 1_{b}$ & Leverage & $\begin{array}{l}\text { Pengungkapan } \\
\text { CSR }\end{array}$ & & D $0,020(0,814)$ & Ditolak \\
\hline $\mathrm{H} 1_{c}$ & $\begin{array}{c}\text { Ukuran } \\
\text { Perusahaan }\end{array}$ & $\begin{array}{l}\text { Pengungkapan } \\
\text { CSR }\end{array}$ & & D $0,101(2,237)$ & Terima \\
\hline $\mathrm{H} 1_{d}$ & $\begin{array}{c}\text { Ukuran Dewan } \\
\text { Komisaris } \\
\end{array}$ & $\begin{array}{c}\text { Pengungkapan } \\
\text { CSR } \\
\end{array}$ & & D $0,454(8,828)$ & Terima \\
\hline $\mathrm{H} 2_{a}$ & Slack resource & Nilai Perusahaan & & D $0,082(4,128)$ & Terima \\
\hline $\mathrm{H} 2_{b}$ & Leverage & Nilai Perusahaan & & D $0,274(15,679)$ & Terima \\
\hline $\mathrm{H} 2_{c}$ & $\begin{array}{c}\text { Ukuran } \\
\text { Perusahaan }\end{array}$ & Nilai Perusahaan & & D $0,290(23,665)$ & Terima \\
\hline $\mathrm{H} 2_{d}$ & $\begin{array}{c}\text { Ukuran Dewan } \\
\text { Komisaris }\end{array}$ & Nilai Perusahaan & & D $0,103(4,539)$ & Terima \\
\hline $\mathrm{H} 2_{e}$ & $\begin{array}{c}\text { Pengungkapan } \\
\text { CSR } \\
\end{array}$ & Nilai Perusahaan & & D $0,342(11,272)$ & Terima \\
\hline $\mathrm{H} 3_{a}$ & Slack resource & Nilai Perusahaan & $\begin{array}{c}\text { Pengungkapan } \\
\text { CSR }\end{array}$ & I $0,148(5,237)$ & Terima \\
\hline $\mathrm{H} 3_{b}$ & Leverage & Nilai Perusahaan & $\begin{array}{c}\text { Pengungkapan } \\
\text { CSR }\end{array}$ & I $0,007(0,812)$ & Ditolak \\
\hline $\mathrm{H} 3_{c}$ & $\begin{array}{c}\text { Ukuran } \\
\text { Perusahaan }\end{array}$ & Nilai Perusahaan & $\begin{array}{c}\text { Pengungkapan } \\
\text { CSR }\end{array}$ & I $0,035(2,194)$ & Terima \\
\hline $\mathrm{H} 3_{d}$ & $\begin{array}{c}\text { Ukuran Dewan } \\
\text { Komisaris }\end{array}$ & Nilai Perusahaan & $\begin{array}{c}\text { Pengungkapan } \\
\text { CSR }\end{array}$ & I $0,155(6,950)$ & Terima \\
\hline
\end{tabular}

*Signifikansi, nilai T-statistik $\geq 1,96$; D: direct effect; I: indirect effect

Sumber: Data sekunder yang diolah

\section{KESIMPULAN DAN SARAN Kesimpulan}

Kesimpulan dalam penelitian ini dapat dikemukakan sebagai berikut: (1) slack resource, ukuran perusahaan dan ukuran dewan komisaris berpengaruh terhadap pengungkapan CSR, namun leverage tidak berpengaruh terhadap pengungkapan CSR; (2) pengungkapan CSR berpengaruh terhadap nilai perusahaan. Bahwa semakin banyak pengungkapan CSR yang dilakukan akan meningkatkan nilai perusahaan; (3) slack resource, ukuran perusahaan, dan ukuran dewan komisaris berpengaruh tidak langsung terhadap nilai perusahaan melalui pengungkapan CSR, sedangkan leverage tidak berpengaruh.

\section{Keterbatasan dan Saran}

Pada pengukuran skor indeks CSR mengandalkan pada penilaian subjektif peneliti. Hal ini karena dalam penentuan skor indeks CSR diperoleh dengan membaca dan menafsirkan isi annual report berdasarkan GRI4 dan tidak adanya standar baku yang dapat dijadikan sebagai pembanding. Indikator GRI4 digunakan karena dapat diterapkan secara universal di semua jenis dan sektor organisasi, skala besar dan kecil, di seluruh dunia dan dirancang sebagai rerangka konsolidasian untuk kinerja pelaporan dengan berbagai koda dan norma keberlanjutan. Saran untuk penelitian selanjutnya apabila menggunakan indikator GRI dalam penentuan indeks CSR, sebaiknya melibatkan pakar yang memang ahli dalam evaluasi pengungkapan CSR perusahaan, serta membandingkan pendapat pakar terebut dengan pendapat peneliti. Jika tidak terdapat perbedaan persepsi, maka penentuan skor indeks pengungkapan CSR menjadi lebih akurat. Selain itu, topik mengenai CSR masih menjadi pembahasan yang menarik untuk diteliti sehingga saran bagi pemerintah maupun standar setters lainnya selaku pemegang otoritas, hendaknya menetapkan standar pelaporan baku berterima umum dan metode evaluasi yang yang jelas bagi perusahaan dalam melaksanakan dan melaporkan CSR.

Keterbatasan lain dalam penelitian ini yaitu asumsi bahwa stakeholder memiliki pemahaman, kesadaran, dan kepekaan yang cukup tentang CSR dan pengungkapannya sebatas hanya dalam annual report. Sedangkan realitanya perusahaan juga melakukan pengungkapan CSR lewat berbagai media. Terdapat kemungkinan bahwa media lain yang tidak diamati dalam penelitian ini lebih efisien memberikan informasi tentang CSR kepada 
stakeholder. Dianjurkan bagi peneliti selanjutnya agar meneliti dari sisi stakeholder eksternal atau penggabungan antara kedua sisi (internal dan eksternal) karena diduga terdapat perbedaan cukup besar tentang pemahaman, kesadaran, dan kepekaan stakeholder tentang pengungkapan CSR.

\section{DAFTAR PUSTAKA}

Belkaoui, A. 1976. dan Karpik P G. 1989. Determinants of the Corporate Decision to Disclose Social Information, Accounting, Auditing and Accountability Journal, Vol. 2 (1): 36-51.

1989. Determinants of the Corporate Decision to Disclose Social Information, Accounting, Auditing and Accountability Journal, Vol. 2 (1): $\quad 36-51$.

Bourgeois, L. J. 1981. On the Measurement of Organizational Slack, The Academy of Management Review, Vol. 6 (1): 29-39.

Capra, F. 1983. The Turning Point: Science, Society and The Rising Culture, London: Bantam Books.

Cowen, S.S., L.B, Ferreri, dan L.D, Parker, 1987. The Impact of Corporate Characteristics on Social Responsibility Disclosure: A Typology and Frequency- Based Analysis, Accounting, Organizations and Society, Vol. 12 (2) : 111-122.

Cyert, R. M., dan March, J. G. 1963. A behavioral theory of the firm. Englewood Cliffs, NJ: Prentice-Hall.

Fadliah. 2012. Determinan Pengungkapan Corporate Social Responsibility (CSR) dan Pengaruhnya Terhadap Kinerja Perusahaan. Disertasi. Universitas Brawijaya. Malang.

Freeman, R. 1984. Strategic Management: A Stakeholder Approach. Marshall, Pitman.

Friedman, Milton. 1962. Capitalism and Freedom, University of Chicago Press.

Hackston, D., dan Milne M. J. 1996. Some Determinant of Social and Enviromental Disclosures in New Zealand Companies. Accounting, Auditingand Accountability Journal, 9 (1): 77-108.

Hartono, Jogiyanto. 2010. Metodologi Penelitian Bisnis: Salah Kaprah dan Pengalaman- Pengalaman. Edisi Pertama. Universitas Gajah Mada. Yogyakarta.
Husnan, S. 2001. Indonesia in Corporate Governance and Finance in East Asia: A Study of Indonesia, Republic of Korea, Malaysia, Philippines, and Thailand. 2, edited by: Zhuang J., David Edwards and Viginita A. Capulong. Asian Development Bank.

Lang, L.H.P., Stulz, R.M, and Walkling, 1989. "Managerial Performance, Tobin's q, and the Gains from Successful Tender Offers". Journal of Financial Economics (September), 137-154.

Lawrence dan Weber,. (2002). Business and society : corporate strategy, Public policy, Ethics (tenth edition). New York : McGraw-Hill.

Mathews, M.R. 1993. Socially Responsible Accounting. Chapman and Hall. London.

Nohria, N., \& Gulati, R. 1996. Is slack good or bad for innovation?. Academy of Management Journal, Vol. 39 (5), 1245-1264.

Novaes, Walter. 2002. Managerial Turnover and Leverage under a Takeover Threat. The Journal of Finance, Vol. LVII, No. 6: 2619- 2650.

Roberts, R. W. 1992. Determinants of Corporate Social Responsibility Disclosure; an Application of Stakeholder Theory. Accounting, Organizations and Society, Vol. 17 (6) : 595-612.

Rofelawaty, Budi. 2010. Analisis Determinan Tingkat Pengungkapan Lingkungan dan Dampaknya Terhadap Reputasi dan Nilai Perusahaan, Studi pada Industri Manufaktur yang terdaftar di Bursa Efek Indonesia, Malang, Disertasi FEUniversitas Brawijaya.

Sari, Agung Mirah Purnama., dan Putu Agus. 2014. Pengaruh Board Size Terhadap Nilai Perusahaan.E-Jurnal Akuntansi Universitas Udayana, Vol. 7.1: 177-191.

Sayekti, Yosefa dan Ludovicus Sensi Wondabio. 2007. Pengaruh CSR Disclosure terhadap Earning Response Coefficient (Suatu Studi Empiris pada Perusahaan yang Terdaftar di Bursa Efek Jakarta). Makalah disampaikan pada Simposium Nasional Akuntansi IX. Makassar, 26-28 Juli 2007.

Seifert, Bruce., Sara A. M., dan Barbara R. B. 2004. Having, Giving and Getting: 
Slack Resources, Corporate Philanthropy and Firm Financial Performance, Business Society, Vol. 43 (2) : 135-161. Sembiring, Eddy R. 2003. Karakteristik Perusahaan Terhadap Pengungkapan Tanggung Jawab Sosial: Studi Empiris pada Perusahaan yang Tercatat di Bursa Efek Jakarta. Jurnal MAKSI Undip, Vol.6 (1).

Sharfman, M. P., Wolf, G., Chase, R. B., dan Tansik D. A. 1988. Antecedent of
Organizational Slack, Academy of Management Review, Vol. 13 (4): 601614.

Tobin's, James, 1969. "A General Equilibrium Approach to Monetary Theory", Journal of Money, Credit and Banking (February), 12-29.

Waddock, S.A., dan Graves S. B. 1997. The Corporate Social Performance-Financial Performance link, Strategic Management Journal, Vol. 18 (4):303-319. 